\title{
Contribution of CD30/CD153 but not of CD27/CD70, CD134/OX40L, or CD137/4-1BBL to the optimal induction of protective immunity to Mycobacterium avium
}

\author{
Manuela Flórido, ${ }^{*}$ Margarida Borges, ${ }^{*}$ Hideo Yagita, ${ }^{\dagger}$ and Rui Appelberg ${ }^{\star, \downarrow, 1}$ \\ *Laboratory of Microbiology and Immunology of Infection, Institute for Molecular and Cell Biology, and ${ }^{\ddagger} I C B A S$, \\ Instituto de Ciências Biomédicas de Abel Salazar, University of Porto, Portugal; and ${ }^{\dagger}$ Department of Immunology, \\ Juntendo University School of Medicine, Tokyo, Japan
}

\begin{abstract}
A panel of monoclonal antibodies specific for CD27 ligand (CD70), CD30 ligand (CD153), CD134 ligand (OX40L), and CD137 ligand (4-1BBL) were screened in vivo for their ability to affect the control of Mycobacterium avium infection in $\mathrm{C} 57 \mathrm{Bl} / 6$ mice. Only the blocking of CD153 led to increased mycobacterial burdens. We then used CD30-deficient mice and found an increase in the proliferation of two strains of $M$. avium in these mice as compared with control animals. The increased mycobacterial growth was associated with decreased $T$ cell expansion and reduced interferon- $\gamma($ IFN- $\gamma)$ responses as a result of reduced polarization of the antigen-specific, IFN$\gamma$-producing $\mathbf{T}$ cells. At late times but not early in infection, the lymphoid cuff surrounding granulomas was depleted in the CD30-deficient animals. This report expands our knowledge about tumor necrosis factor superfamily members involved in the immune responses to mycobacterial infection by identifying CD30-CD153 interactions as required for optimal immune control of $M$. avium infection. J. Leukoc. Biol. 76: 1039-1046; 2004.
\end{abstract}

Key Words: mycobacteria $\cdot$ macrophages $\cdot$ cell-mediated immunity

\section{INTRODUCTION}

Tumor necrosis factor (TNF) and its receptors are structurally related to an increasing number of molecules belonging to two superfamilies: the TNF superfamily (TNFSF) and the TNF receptor superfamily (TNFRSF). These receptor-ligand pairs of molecules play diverse roles in inflammation, in the immune response, in organogenesis of lymphoid and bone tissues and other body structures, and in apoptosis $[1,2]$. Although most information about the role of these molecules has been obtained studying the cytokines TNF and lymphotoxin and their receptors, newer data about other members of these families have highlighted their participation in the regulation of the immune response. Thus, the engagement of certain members of the TNFRSF appears to be important for costimulation of T cell immunity [2]. Among these, recent data have emerged about the role played by the TNFRSF members CD27 (TNFRSF7), CD30 (TNFRSF8), CD134 (TNFRSF4 or OX40), and CD137 (TNFRSF9 or 4-1BB) and their ligands CD70 (TNFSF7), CD153 (TNFSF8), OX40L (TNFSF4), and 4-1BBL (TNFSF9), respectively.

CD27/CD70 interactions participate in the early phases of $\mathrm{T}$ cell responses [2]. Engaging CD27 on T cells activates these cells, leading to cytokine secretion and proliferation, and potentiates the activity of other accessory molecules [3]. Mice deficient in CD27 have impaired responses to influenza virus and reduced $\mathrm{T}$ cell memory generation [4]. Conversely, chronic in vivo triggering of CD27 by expression of a CD70 transgene led to massive activation and proliferation of $\mathrm{T}$ cells with conversion of naïve cells into cells with an activated/memory phenotype $[5,6]$. In vivo experimental models of experimental autoimmune encephalomyelitis (EAE), an inflammatory condition dependent on a type $1 \mathrm{~T}$ cell response, have highlighted a role for CD27/CD70 in the induction of the T cells responsible for such neurological pathology [7].

The function of CD30 is controversial, as it has been said to be a marker for T helper cell type 2 (Th2) cells [8] and required for T cell-negative selection [9], and both claims have been questioned subsequently $[10,11]$. CD30 expression on T cells is induced by interleukin (IL)-4 and CD28 stimulation [12, 13], and its engagement may lead to enhanced proliferation [12] or on the contrary, prime the lymphocyte for apoptotic death by promoting TNFR-associated factor (TRAF) 2 degradation [14, 15]. A virally encoded homologue of CD30 was shown to block the development of inflammation and interferon- $\gamma(\mathrm{IFN}-\gamma)$ production during priming with mycobacterial antigens [16], but nothing is known about the role of CD30 in mycobacterial infections.

Early $\mathrm{T}$ cell responses appear not to require the participation of OX40/OX40L or 4-1BB/4-1BBL, but subsequent accumulation of effector and memory cells does involve the activity of these molecules [2]. The role of OX40/OX40L in the development of Th2 responses is well documented, namely in an

\footnotetext{
${ }^{1}$ Correspondence: Laboratory of Microbiology and Immunology of Infection, Institute for Molecular and Cell Biology, Rua do Campo Alegre 823, 4150-180 Porto, Portugal. E-mail: rappelb@ibmc.up.pt

Received November 19, 2003; revised May 14, 2004; accepted July 14, 2004; doi: 10.1189/jlb.1103572.
} 
experimental model of asthma [17] and in an infection model with Leishmania major [18]. In contrast, OX40 deficiency did not affect the protective Thl responses in resistant mice infected with L. major [19]. Also, blocking the activity of OX40L did not affect the development of pathogenic, IFN- $\gamma$-producing $\mathrm{T}$ cells during EAE but still protected against the disease by reducing the migration of those cells [20]. Similar protection from EAE was observed after administration of soluble OX40 [21]. In contrast, IFN- $\gamma$ responses to lymphocytic choriomeningitis virus (LCMV) were reduced in OX40-deficient animals as compared with control mice [22], and OX40 ligand-deficient animals had impaired IFN- $\gamma$ responses during hypersensitivity reactions and in mixed leukocyte reactions initiated by allogeneic dendritic cells [23]. Triggering of 4-1BB (CD137) on T cells appears to stimulate IFN- $\gamma$ responses [24-26]. In one study, 4-1BBL-deficient mice were particularly deficient in the CD8 T cell response to infection by LCMV [27], whereas in another study, 4-1BBL-deficient mice mounted normal, cytolytic responses to LCMV but reduced responses to influenza virus [28].

Here, we studied the effects of neutralizing single pairs of the TNFRSF/TNFSF members discussed above in the development of protective immunity to Mycobacterium avium. Of the four pairs of interacting molecules, we identified CD30/CD153 interactions as necessary for the optimal induction of immunity to $M$. avium and confirmed these observations using a mouse model where the CD30-encoding gene was disrupted.

\section{MATERIALS AND METHODS}

\section{Mice}

Female C57Bl/6 mice were purchased from Harlan Iberica (Barcelona, Splain). C57B1/6-CD30 $0^{-/}\left(\right.$B6.CD30 $\left.{ }^{-/-}\right)$mice were kindly supplied by Dr. Tak Mak (Amgen, Toronto, Canada) and bred in our facilities.

\section{Bacteria}

M. avium strain 25291, exhibiting a smooth transparent (SmT) morphotype, was obtained from American Type Culture Collection (Manassas, VA). M. avium strains 2447 and 1983, with SmT morphotype, were isolated from an AIDS patient and a human immunodeficiency virus-negative patient, respectively [29]. Mycobacteria were grown in Middlebrook 7H9 medium (Difco, Detroit, MI) containing 0.04\% Tween 80 (Sigma Chemical Co., St. Louis, MO) at $37^{\circ} \mathrm{C}$ until the mid-log phase of growth. Bacteria were harvested by centrifugation and resuspended in a small volume of saline containing $0.04 \%$ Tween 80. The bacterial suspension was sonicated briefly with a Branson sonifier (Danbury, CT) to disrupt bacterial clumps, diluted, and stored in aliquots at $-70^{\circ} \mathrm{C}$ until used. One aliquot was thawed at $37^{\circ} \mathrm{C}$ and used to determine the concentration of mycobacteria in the inocula after plating serial dilutions of the suspension in a Middlebrook 7H10 agar medium (Difco) supplemented with oleic acid-albumin-dextrose-catalase. Before inoculation, bacterial aliquots were thawed at $37^{\circ} \mathrm{C}$ and diluted in saline to the desired concentration.

\section{In vivo infection}

Mice were infected intravenously (i.v.) with $10^{6}$ colony-forming units (CFU) of M. avium through a lateral tail vein. Infected mice were killed at different time-points of infection, and the livers, spleens, and lungs were aseptically collected and homogenized in a $0.04 \%$ Tween 80 solution in distilled water. The number of CFU of $M$. avium in the organs of the infected mice was determined by serial dilution and plating of the tissue homogenates on $7 \mathrm{H} 10$ agar medium. The number of bacterial colonies was counted after culture for
2 weeks at $37^{\circ} \mathrm{C}$. Statistical comparisons of the mycobacterial loads between deficient and control mice were performed using the Student's $t$-test.

\section{In vivo antibody treatments}

$\mathrm{C} 57 \mathrm{Bl} / 6$ mice were treated with monoclonal antibodies $(\mathrm{mAb})$ specific for CD70 [FR70, rat immunoglobulin G (IgG)2b; ref. 30], OX40L (RM134L, rat IgG2b) [31], CD153 (RM153, rat IgG2b) [32], or 4-1BBL (TKS1, rat IgG2a) [33]. All these $\mathrm{mAb}$ were purified from ascites by protein $\mathrm{G}$ affinity chromatography. Nonimmune $\mathrm{IgG}$ was purified from sera of normal rats by protein $\mathrm{G}$ chromatography. mAb or nonimmune IgG were given intraperitoneally, starting on the day of the infection and treating twice a week for up to 3 months, using $250 \mu \mathrm{g}$ antibody per dose.

\section{In vitro stimulation of splenic cells}

Single-cell suspensions from spleens of each of the infected mice were prepared by teasing portions of the spleen with forceps in Dulbecco's modified Eagle tissue-culture medium (DMEM; Life Technologies, Paisley, UK), supplemented with $10 \%$ fetal calf serum (FCS; Life Technologies). Erythrocytes were lysed by incubation of the cell suspensions with hemolytic buffer (155 $\mathrm{mM} \mathrm{NH} 4 \mathrm{Cl}, 10 \mathrm{mM} \mathrm{KHCO3,pH} \mathrm{7.2)} \mathrm{for} 5 \mathrm{~min}$ at room temperature. The cell suspensions were then thoroughly washed with Hanks' balanced salt solution (Life Technologies) and resuspended in DMEM with 10\% FCS. Cells were cultivated at a density of $2 \times 10^{5}$ cells/well in a U-bottom, 96-well microtiter plate. Cells were incubated in triplicate in DMEM with 10\% FCS with no further stimulus or in the presence of mycobacterial envelope proteins (4 $\mu \mathrm{g} / \mathrm{ml}$ ). Supernatants from the cultures were collected after $96 \mathrm{~h}$ of culture, and the IFN- $\gamma$ produced was quantified by a two-site sandwich enzyme-linked immunosorbent assay (ELISA) method using anti-IFN- $\gamma$-specific, affinity-purified $\mathrm{mAb}$ (R4-6A2 as capture and biotinylated AN-18 as detecting antibody), and a standard curve was generated with known amounts of recombinant murine IFN- $\gamma$ (Genzyme, Cambridge, CA). The sensitivity of the assay was 30 $\mathrm{pg} / \mathrm{ml}$. To determine the frequency of IFN- $\gamma$-producing cells, CD $4^{+} \mathrm{T}$ cells were purified as described below and studied in an ELISpot assay. Microtiter plates were coated with $0.25 \mu \mathrm{g} /$ well monoclonal anti-mouse IFN- $\gamma$ (cell line R4-6A2), and after overnight incubation at $4^{\circ} \mathrm{C}$, plates were emptied and blocked for $2 \mathrm{~h}$ with phosphate-buffered saline (PBS) containing $3 \%$ bovine serum albumin (BSA) and 0.05\% Tween 20 and washed four times with PBS/Tween 20. Cells were cultured directly in the microtiter plates in duplicates in the presence of $4 \mu \mathrm{g} / \mathrm{mL}$ mycobacterial envelope proteins for $24 \mathrm{~h}$ at $37^{\circ} \mathrm{C}$ in $7 \% \mathrm{CO}_{2}$ atmosphere. For each cell sample, six serial, twofold dilutions were done from a starting concentration of $4 \times 10^{5} \mathrm{CD}^{+}$cells plus $2 \times$ $10^{6}$-irradiated antigen-presenting cells (APC)/well. Cells were removed by washing the plates, and cytokine secretion was detected using $0.25 \mu \mathrm{g} / \mathrm{well}$ biotin-labeled rat anti-mouse $\mathrm{mAb}$ (cell line AN18) and $0.1 \mu \mathrm{g} /$ well phosphatase-conjugated streptavidin. The enzyme reaction was developed with a solution of $0.9 \mathrm{mg}$ 5-bromo-4-chloro-3-indolylphosphate per ml substrate buffer (0.74 mM MgCl2, 0.1\% Triton-X405, 9.6\% 2-amino-2-methyl-1-propanol, $\mathrm{pH} 10.25)$ containing $0.6 \%$ agarose. Blue spots were counted microscopically, and the relationship between the number of spots developed per well and the number of input cells was determined. Mycobacterial envelope proteins were prepared from $M$. avium as described previously [34].

\section{Purification and culture of $\mathrm{CD} 4^{+} \mathrm{T}$ cells}

Cells were suspended in PBS containing 0.5\% BSA and 2 mM EDTA, pH 7.2, at a concentration of $10^{8}$ cells $/ \mathrm{ml}$ and incubated with micro-beads coated with anti-CD4 mAb (10 $\mu \mathrm{l} / 10^{7}$ cells; clone L3T4; Miltenyi Biotec, Germany) for 20 min at $4^{\circ} \mathrm{C}$. Cells were washed, resuspended in PBS/BSA/EDTA at a concentration of $2 \times 10^{8}$ cells $/ \mathrm{mL}$, and filtered through a $70-\mu \mathrm{m}$ nylon cell strainer (BD Falcon, BD Biosciences, San Jose, CA) to remove cell debris and cell clumps. CD4 ${ }^{+} \mathrm{T}$ cells were positively selected by using MidiMACS separation columns (Miltenyi Biotec), as described in the instructions from the manufacturer. The selected cells were resuspended in complete DMEM medium and cultured in triplicates in a 96-well plate at a density of $1 \times 10^{6}$ cells $/ \mathrm{ml}$ in the presence of irradiated (5000 Rad), nucleated spleen cells as APC at a density of $5 \times 10^{6}$ cells $/ \mathrm{mL}$ and stimulated with mycobacterial envelope proteins (4 $\mu \mathrm{g} / \mathrm{mL}$ ) or concanavalin A (Con A; $4 \mu \mathrm{g} / \mathrm{mL}$ ) for $72 \mathrm{~h}$ at $37^{\circ} \mathrm{C}$ in a $7 \% \mathrm{CO}_{2}$ atmosphere or used in the ELISpot assay as described. 


\section{Lymphocyte proliferation assay}

Cell proliferation was measured by $\left[{ }^{3} \mathrm{H}\right]$-labeled deoxy-thymidine $\left(\left[{ }^{3} \mathrm{H}\right]-\mathrm{TdR}\right)$ incorporation. Briefly, proliferative responses were assessed after $48 \mathrm{~h}$ of culture in a humidified atmosphere of $7 \% \mathrm{CO}_{2}$. Cultures were pulsed with 0.5 $\mu \mathrm{Ci}\left[{ }^{3} \mathrm{H}\right]-\mathrm{TdR}$ (Amersham, Little Chalfont, UK) for $24 \mathrm{~h}$ before harvesting, and incorporation of $\left[{ }^{3} \mathrm{H}\right]-\mathrm{TdR}$ was measured using liquid scintillation. Results are expressed as mean counts per minute (cpm) of triplicate cultures.

\section{Reverse transcriptase-polymerase chain reaction (RT-PCR)}

In vivo production of IL-12p40 was studied by RT-PCR analysis. Total RNA was extracted from a small portion of liver tissue of individual mice after lysis in guanidinium isothiocyanate buffer. Reverse transcription was performed using an Invitrogen kit. The message for hypoxanthine phosphorybosyltransferase (HPRT) was amplified using specific primers. All samples were standardized for approximately the same HPRT expression level, and this level was verified to be below saturation point by comparison with a curve generated by serial dilutions of one of the cDNAs. The same amounts of cDNA were then used to PCR-amplify the IL-12p40 message, using primers with the following sequences: sense: CGT GCT CAT GGC TGG TGC AAA; antisense: CTT CAT CTG CAA GTT CTT GGG. The PCR products of both messages were run in an agarose gel containing ethidium bromide. The gel was photographed, and the image was analyzed to evaluate band intensity using ImageQuant software.

\section{Flow cytometry}

For the immunofluorescence staining, $10^{6}$ cells were incubated in a 96-well microtiter plate with fluorescein isothiocyanate (FITC)-conjugated anti-CD4 antibody (dilution 1:100) and phycoerythrin (PE)-conjugated anti-CD8 antibody (dilution 1:100) or FITC-conjugated anti-CD19 antibody (dilution 1:100) and PE-conjugated antimembrane-activated complex 1 antibody (dilution 1:100) in PBS containing 3\% fetal calf serum (FCS). All antibodies were from BD PharMingen (San Diego, CA). The cells were washed twice with PBS containing 3\% FCS, and propidium iodide (Sigma Chemical Co.) was added to the cells at a final concentration of $1 \mu \mathrm{g} / \mathrm{mL}$ to allow the exclusion of dead cells. The analysis of the cell populations was based on the acquisition of 10,000 events in a Becton Dickinson FACSort equipped with CELL-Quest software.

\section{Histology}

Portions of the organs of the infected mice were fixed in buffered formaldehyde and embedded in paraffin. Sections were stained with hematoxylin and eosin or stained for acid-fast bacteria with carbol-fuchsin and counterstained with methylene blue.

\section{RESULTS}

We initially screened our panel of $\mathrm{mAb}$ in two independent experiments using mice infected with strain 2447 of M. avium. Neither anti-CD70 (FR70) nor anti-OX40 ligand (RM134L) $\mathrm{mAb}$ affected the course of the infection in terms of mycobacterial growth (Fig. 1, upper row). In contrast, administration of anti-CD153 mAb (RM153), which blocks its interaction with CD30, resulted in the exacerbation of the infection as detected at the 12th week post-infection (Fig. 1, upper row). In the second experiment, we studied the effect of the neutralization of interactions between CD137 and its ligand (4-1BBL) following administration of the TKS- $1 \mathrm{mAb}$ and found no effect on mycobacterial proliferation (Fig. 1, lower row). When T cells from spleens of these groups of animals were stimulated in vitro with $M$. avium antigen, no effects on the amounts of IFN- $\gamma$ secreted were observed for any group as compared with controls (data not shown).
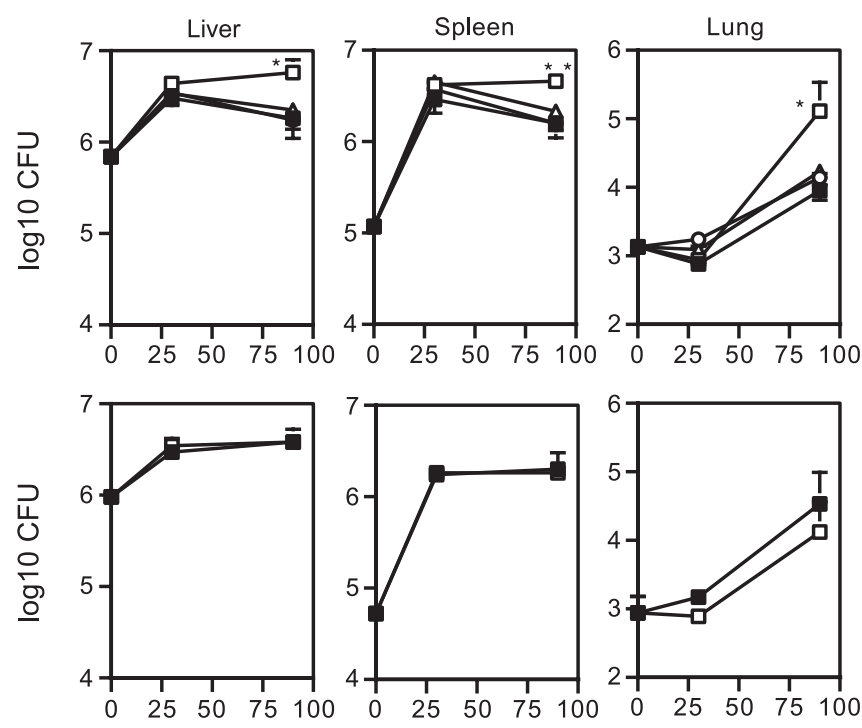

Time (days)

Fig. 1. Proliferation of $M$. avium 2447 in $\mathrm{C} 57 \mathrm{Bl} / 6$ mice treated with nonimmune rat $\operatorname{IgG}(\square)$ or specific antibodies directed against CD153 ( $\square$, upper row), OX40L (CD134L; $\bigcirc$, upper row), $\mathrm{CD} 70$ ( $\triangle$, upper row), or the ligand for 4-1BB (CD137; $\square$, lower row). Data points represent the means of the $\log 10 \mathrm{CFU}$ in the organs of five mice per group, and the bars represent the SD. Statistically significant differences between the treated and control groups are labeled with $*(P<0.05)$ or $* *(P<0.01)$.

Given the protracted nature of the infection and the need for rather long periods of antibody administration, which may result in ineffectiveness of the treatment along its course, we then used CD30-deficient mice to validate our results obtained from the antibody treatments. B6.CD30 $0^{-1-}$ mice were infected with the strain of $M$. avium used in the first set of experiments as well as with two additional ones, a less virulent strain ( $M$. avium 1983) and a highly virulent strain, which is not controlled by the immune response of the infected mice (M. avium ATCC 25291) [35, 36]. As shown in Figure 2, B6.CD30 ${ }^{-1-}$ mice were more susceptible to strains 2447 and 1983 than control B6 animals. Not surprisingly, both mouse strains allowed similar growth of the highly virulent 25291 strain, which resists the immune response effector mechanisms [35].

Histologically, there were no differences in the overall architecture of the granulomas formed in the wild-type as compared with the CD30-deficient mice until the 3rd month of infection (data not shown). However, at later time-points of infection (238 days) with strain 2447 , a marked depletion of the lymphoid cuff surrounding the granulomas was evident (Fig. 3). The area depleted of lymphocytes appeared as an empty area, where fibrotic material could be visualized, and corresponded to where the lymphocytes were previously found in the granulomas of the mutant strain. When flow cytometric analysis of the spleen cell populations was performed, some differences were detected early in infection (Table 1). CD4 ${ }^{+}$ $\mathrm{T}$ cells expanded less in CD30-deficient than in control mice infected with strain 2447 (2.7-fold as compared with 3.4-fold at day 30 of infection) and did not expand in CD30-deficient mice in response to infection with strain 1983, whereas a delayed expansion was observed in the controls. Both mouse strains 

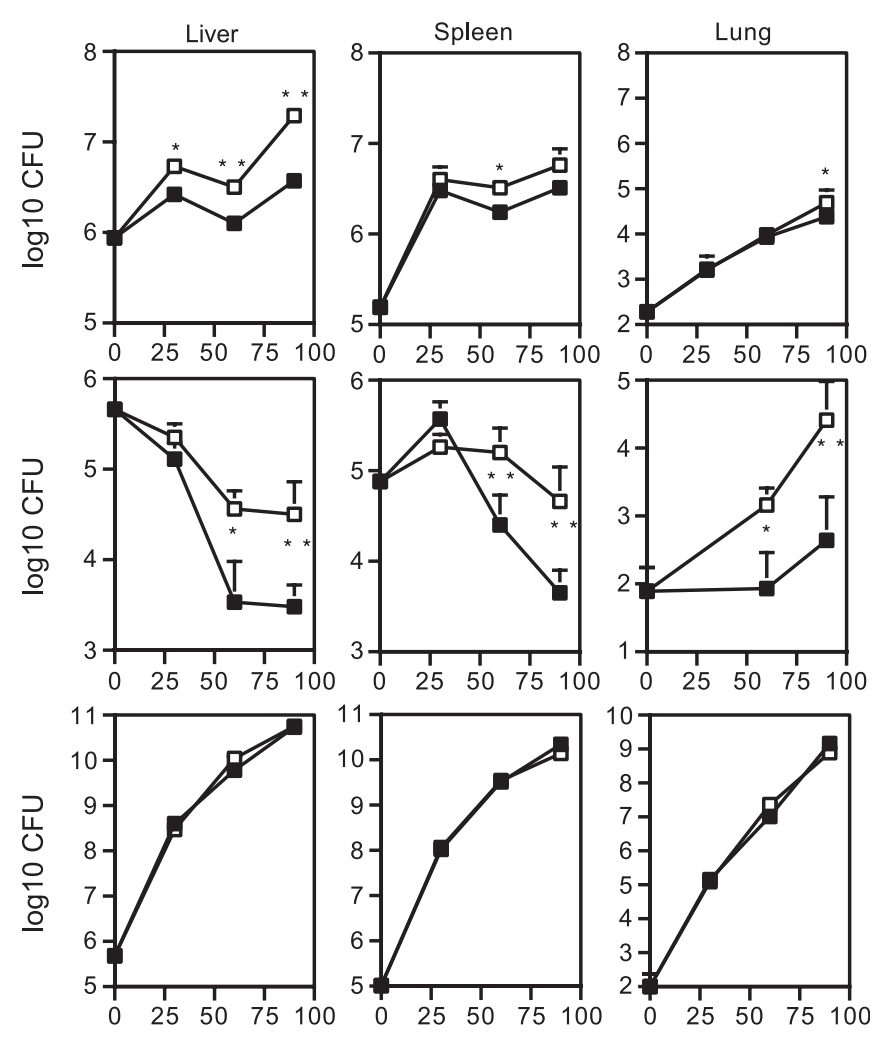

Time (days)

Fig. 2. Proliferation of M. avium strains 2447 (top row), 1983 (middle row), or 25291 (bottom row) in $\mathrm{C} 57 \mathrm{Bl} / 6$ (closed symbols) or B6.CD30 ${ }^{-1-}$ (open symbols) mice. Statistically significant differences between the two groups of mice $(\mathrm{n}=5)$ are labeled with $*(P<0.05)$ or $* *(P<0.01)$. The results with strain 2447 were confirmed in an independent experiment.

exhibited profound $\mathrm{T}$ cell loss during infection with the highly virulent 25291 strain as previously shown [35, 36]. A similar deficiency was evident for B cells during infection with strain 1983 and at 90 days, with strain 2447 . Some reduction in the accumulation of macrophages was also evident in CD30-deficient mice during the infection with strain 1983. At 238 days of infection with strain 2447 , the numbers of lymphoid cells were further reduced in the infected CD30-deficient mice as compared with control-infected mice (Table 2): $\mathrm{CD}^{+}$and $\mathrm{CD}^{+} \mathrm{T}$ cells from infected B6.CD30 ${ }^{-1-}$ mice were $31 \%$ of those in infected $\mathrm{C} 57 \mathrm{Bl} / 6$ mice and $55 \%$ and $35 \%$, respectively, of uninfected B6.CD30 ${ }^{-1-}$ mice. CD19 ${ }^{+}$B cells from infected B6.CD30 ${ }^{-1-}$ mice were $8 \%$ of those in infected $\mathrm{C} 57 \mathrm{Bl} / 6$ mice and $18 \%$ of those in age-matched, noninfected B6.CD30 ${ }^{-1-}$ animals. No reduction in lymphoid cell numbers was induced by infection in $\mathrm{C} 57 \mathrm{Bl} / 6$ mice. At this late timepoint of infection, the increased mycobacterial loads observed in CD30-deficient mice as compared with B6 animals were still apparent (Table 2). In vitro proliferation assays did not provide any evidence for a defect in lymphocyte proliferation in the mutant mice. Spleen cells from infected mice showed reduced proliferation in response to Con A as compared with cells from noninfected controls, a defect previously reported to be associated with the extensive macrophage activation induced by infection [37]. The reduction was bigger in C57Bl/6 mice (from
$53,160 \pm 13,007 \mathrm{cpm}$ in controls to $6648 \pm 2009 \mathrm{cpm}$ in infected mice, corresponding to an $87.5 \%$ reduction) than in B6.CD30 ${ }^{-/-}$mice (from $59,212 \pm 9971 \mathrm{cpm}$ in controls to $24,240 \pm 99,776 \mathrm{cpm}$ in infected mice, corresponding to a $58.4 \%$ reduction). Proliferation of spleen cells from infected animals in response to specific antigen was closer to background levels and showed no significant differences between the two mouse strains $(2038 \pm 449 \mathrm{cpm}$ in controls and $3353 \pm 1093 \mathrm{cpm}$ in $\mathrm{CD} 30^{-/-}$mice).

To further understand the basis of the increased susceptibility of CD30-deficient mice to $M$. avium, we studied the production of IFN- $\gamma$ during infection, as this is a pivotal cytokine in the protective immunity against this mycobacterium $[35,38]$. No differences in the amounts of IFN- $\gamma$ found in the sera of infected animals were found (data not shown). However, when spleen cells were stimulated in vitro, IFN- $\gamma$ secretion was consistently lower in CD30-deficient mice as compared with wild-type animals during infection with strain 2447 at all time-points tested and at day 60 of infection with the other two strains (Table 3). In contrast with what has been described in $M$. avium infections of other immune-deficient mice, such as those lacking expression of CD40 or of the Toll-like receptor $2[39,40]$, no decrease in IL-12p40 expression was observed during infection of CD30-deficient as compared with control animals (Fig. 4).

To get an insight into the nature of the deficient cytokine response, $\mathrm{CD}^{+}{ }^{+} \mathrm{T}$ cells from day $30 \mathrm{M}$. avium 2447 -infected mice were purified by magnetic cell sorting, and the number of antigen-specific IFN- $\gamma$-producing cells was determined upon culture of serial 1:2 dilutions of these cells plated with fixed numbers of irradiated spleen cells as APC using an ELIspot assay (Fig. 5). As shown, the decrease in the bulk IFN- $\gamma$ responses in whole spleen cell cultures described before and confirmed in this experiment (not shown) was not a result of a decrease in the frequency of responding cells (Fig. 5A) but of a decreased ability of those cells to secrete IFN- $\gamma$ on a per-cell basis (Fig. 5B).

\section{DISCUSSION}

Many elements of the TNFSF and TNFRSF play a role in modulating the immune response $[1,2]$. Here, we performed a preliminary screening of the possible role played by four different ligand-receptor pairs using a panel of $\mathrm{mAb}$ previously
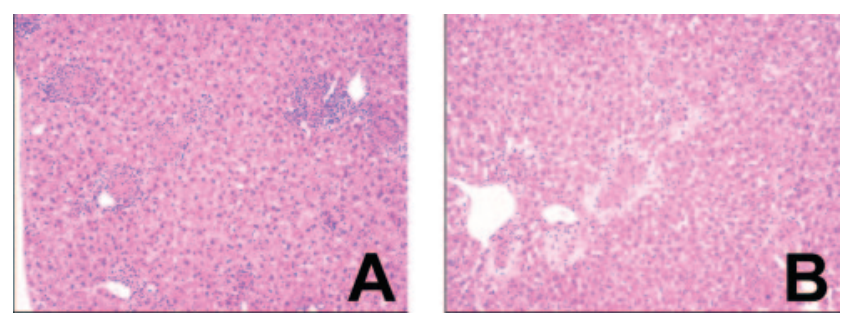

Fig. 3. Histological analysis of infected livers at 8 months of infection of C57Bl/6 (A) or B6.CD30 ${ }^{-1-}$ (B) mice with $M$. avium 2447. Representative areas were chosen from the two strains studied. Four animals of each strain were used in this study. 
TABLE 1. Spleen Cell Populations from C57B1/6 or B6.CD30 ${ }^{-1-}$ Mice ( $\mathrm{n}=5$ Per Group) during Infection with M. avium Strains 2447, 1983, and 25291

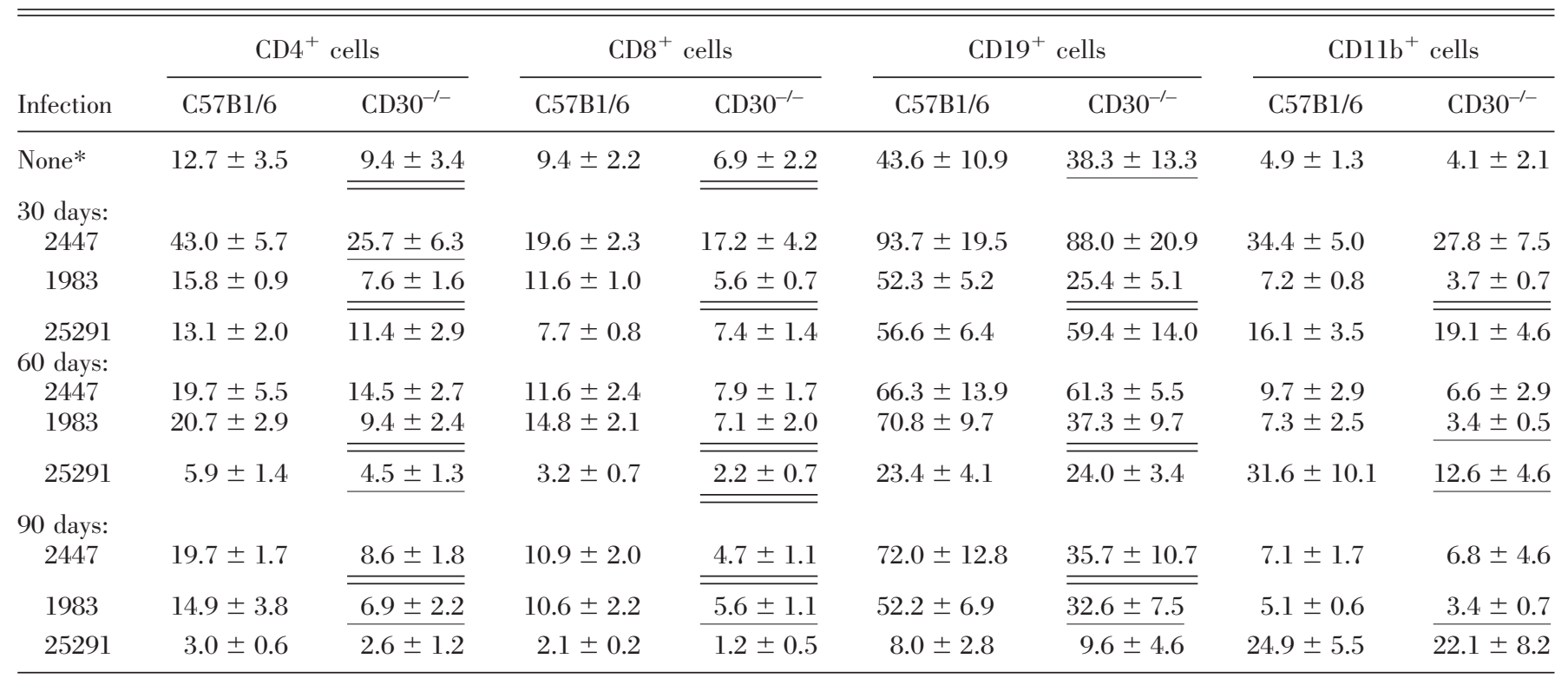

At the indicated time-points of infection by any of the three strains of $M$. avium, spleen cells were analyzed by flow cytometry. Data are shown as mean $\pm \mathrm{SD}$, and statistically significant differences between the two mouse strains are indicated as single-underlined $(P<0.05)$ or double-underlined $(P<0.01)$ values, after performing Student's $t$-test. * The means and SD were calculated from of all groups of uninfected mice used in parallel with the infected animals at all time-points of the three independent infections $\left(\mathrm{n}=28\right.$ for $\mathrm{C} 57 \mathrm{~B} 1 / 6 ; \mathrm{n}=30$ for $\left.\mathrm{CD}^{-/-}\right)$.

shown to be effective in vivo in altering the immune response in different models of infectious or inflammatory diseases [7, $17,18,20]$. Of the four antibodies, the one that specifically targets CD153, the ligand for CD30, was found to exacerbate the infection by one strain of $M$. avium. We then used mice bearing a genetic deficiency in CD30 to further study the role of these molecules in immunity to M. avium. We found that CD30 was required for the optimal generation of protective immunity to two different strains of $M$. avium, which are

TABLE 2. Consequences of Long-Term Infection with $M$. avium 2447

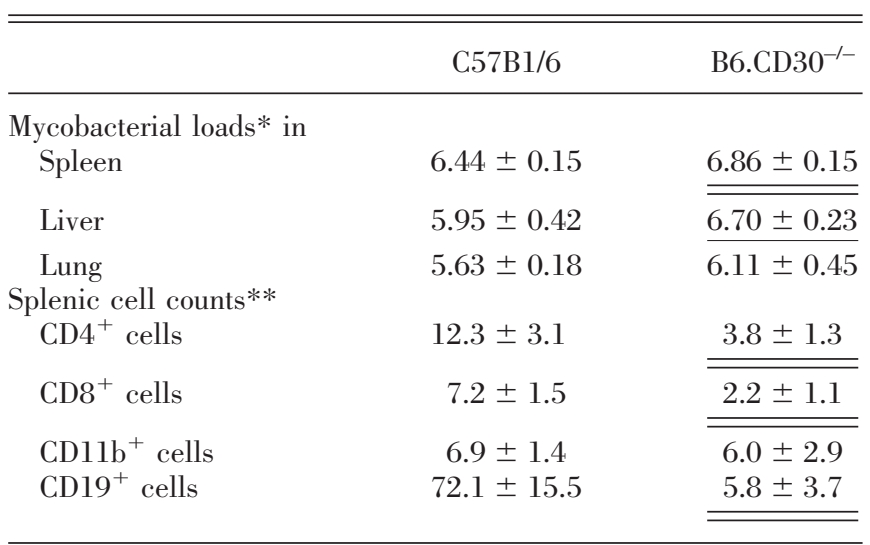

C57B1/6 and B6.CD30 ${ }^{-1-}$ mice were infected i.v. with $10^{6} \mathrm{CFU}$ of $M$. avium and studied 8 months post-inoculation by performing viable counts, analyzing spleen cell populations, and performing histological analysis of granuloma structure (see Fig. 3). Data are shown as mean \pm SD, and statistically significant differences between the two mouse strains are indicated as singleunderlined $(P<0.05)$ or double-underlined $(P<0.01)$ values, after performing Student's $t$-test. * Mycobacterial loads are shown as the mean $\log 10 \mathrm{CFU} /$ organ $\pm 1 \mathrm{SD}$. ** The values shown represent the arithmetic means of the numbers of the different cell populations in millions per spleen. normally controlled by the host. The increased susceptibility was associated with a smaller expansion of the T cells during infection, namely of the $\mathrm{CD}^{+}{ }^{+}$subset, which includes the protective T cells. The increased susceptibility was also associated with decreased priming of $\mathrm{T}$ cells for the secretion of IFN- $\gamma$, and there was evidence for a late defect in granuloma maintenance. These immune deficiencies associated with the lack of CD30 were of small magnitude and were associated

TABLE 3. Priming of T cells from C57B1/6 or B6.CD30 ${ }^{-/-}$Mice for Secretion of IFN- $\gamma$ during Infection with $M$. avium Strains 2447, 1983, and 25291

\begin{tabular}{ccr}
\hline \hline Infection & C57B1/6 & \multicolumn{1}{c}{$\mathrm{CD}^{-/-}$} \\
\hline 30 days: & & \\
2447 & $2904 \pm 1271$ & $\frac{1168 \pm 193}{816 \pm 527}$ \\
1983 & $3848 \pm 2110$ & $1321 \pm 208$ \\
25291 & $1495 \pm 309$ & $\underline{946 \pm 429}$ \\
60 days: & $2405 \pm 916$ & $\underline{1076 \pm 311}$ \\
2447 & $4050 \pm 2084$ & $\underline{95 \pm 46}$ \\
1983 & $200 \pm 49$ & $\underline{1490 \pm 783}$ \\
25291 & $3091 \pm 504$ & $1626 \pm 1220$ \\
90 days: & $4030 \pm 1140$ & $27 \pm 5$ \\
2447 & N.D. \\
1983 & 25291 &
\end{tabular}

At the indicated time-points of infection by any of the three strains of $M$. avium, spleen cells were stimulated in vitro with homologous mycobacterial envelope proteins, and the amounts of IFN- $\gamma$ secreted into the supernatants were measured by ELISA and shown here as mean \pm SD in $\mathrm{pg} / \mathrm{ml}$ culture medium. Cells from noninfected mice or unstimulated cells from infected animals produced negligible amounts of cytokine. N.D. = Not detectable. Statistically significant differences between the two mouse strains are indicated as single-underlined $(P<0.05)$ values after performing Student's $t$-test. 
Fig. 4. RT-PCR products from samples of RNA taken from the livers of uninfected mice or from mice infected for 15 days with $M$. avium 2447. Primers specific for HPRT or IL-12p40 were used in nonsat-

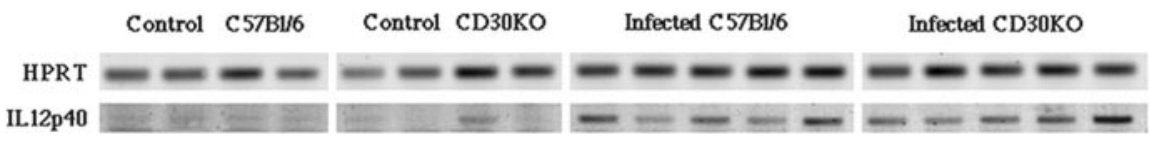
urating conditions. The time-point chosen was previously shown to be one when other immune-deficient animals showed defects in expression of the gene.

with significant, albeit limited, exacerbation of the infection. Thus, although impacting on the immune response and resistance to $M$. avium, CD30 plays a marginal role as compared with other elements of the immune system. However, this is the first time such an involvement in immunity to infection is shown. It will be interesting to analyze other infection models and assess whether more important contributions may be found with other pathogens. The deficiency in CD30 expression did not affect the course of the infection by a strain of high virulence, which escapes protective immunity. The infection with this strain induces a strong IFN- $\gamma$ response and marked macrophage activation, but the mycobacterial strain escapes the effector mechanisms of the immune response through asyet unidentified mechanisms. It is thus not surprising that a reduction in the development of the immune response had no effect on the growth of a strain able to resist such response.

Several TNF and TNFR family members have been shown to be involved in the in vivo induction of immune responses, namely during viral infections and experimentally induced autoimmune disorders [4, 7, 20, 21, 27, 28]. In models of infectious diseases, CD134 was incriminated in the induction of disease-promoting Th2 responses during experimental, cutaneous leishmaniasis [18], and a soluble viral homologue of
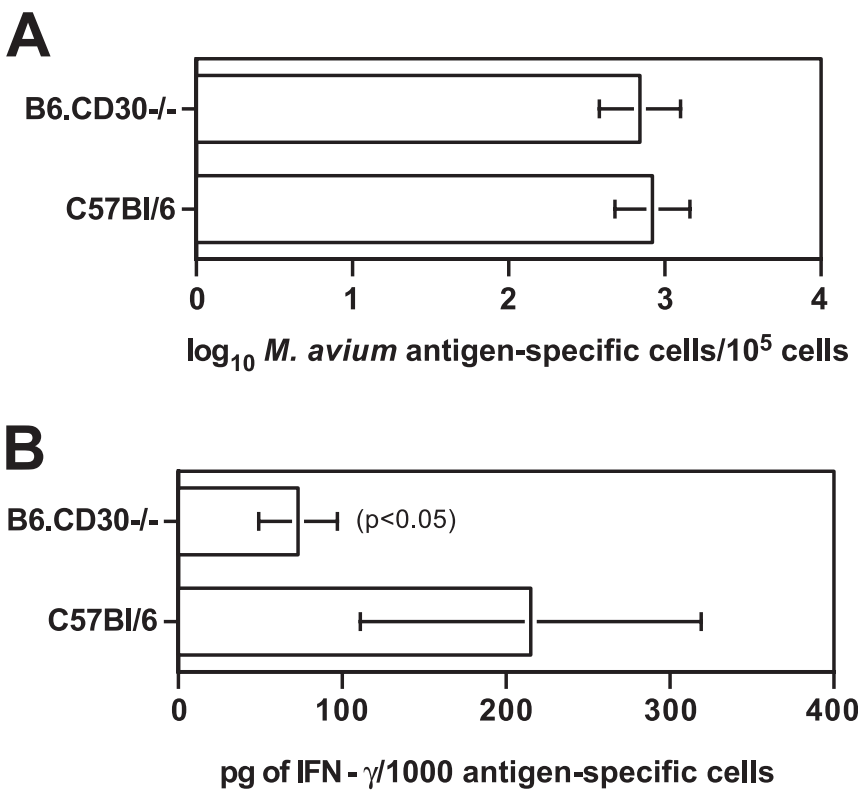

Fig. 5. IFN- $\gamma$ produced by purified $\mathrm{CD}^{+} \mathrm{T}$ cells from $\mathrm{C} 57 \mathrm{Bl} / 6$ or B6.CD30 ${ }^{-1-}$ mice infected for 30 days with $M$. avium 2447. (A) Frequency of IFN- $\gamma$-producing $\mathrm{CD}^{+}{ }^{+} \mathrm{T}$ cells stimulated with $M$. avium antigen as determined by ELISpot assay. (B) The amount of IFN- $\gamma$ produced by fixed numbers of $\mathrm{CD}_{4}^{+} \mathrm{T}$ cells was corrected for the frequency of responsive cells, and the values obtained show the amount of IFN- $\gamma$ produced per 1000 cells. Both cultures were performed from the same purified $\mathrm{CD} 4^{+} \mathrm{T}$ cells, and the data represent the means and SD from values obtained from individual animals. Irradiated spleen cells from uninfected C57Bl/6 mice were used as APC.
CD30 produced by ectromelia virus was shown to interfere with the generation of Thl responses [16]. Our data extend these observations about the role of TNFRSF members in the induction of the immune response to a mycobacterial species. Several members of the TNFSF and TNFRSF have been shown to be involved in protective immunity to mycobacteria with special relevance to TNF itself and lymphotoxin [41-47]. We also showed that CD40 is required for optimal induction of protective immunity to $M$. avium [36]. It is thus apparent that different molecules of these families cooperate to orchestrate an efficient, protective immune response. Future work should make use of combinations of more than one deficiency to assess how redundant these mechanisms are.

The mechanism whereby CD30 promotes protective immunity to $M$. avium is still undefined. It has been shown that IL-4 may increase CD30 expression in T cells [13] and that during CD30 signaling, the adaptor molecule TRAF2 is rapidly depleted, leading to increased sensitivity to death signals [14]. Consistent with these findings, Seah and Rook [15] described an in vitro system where peripheral blood leukocytes from tuberculosis patients had increased IL-4 secretion in response to the mycobacterial antigens and that $\mathrm{CD}^{+} 0^{+}$cells showed increased susceptibility to TNF-induced apoptosis correlating with decreased amounts of intracellular TRAF2 levels. A simplistic analysis of these data would thus suggest that CD30deficient T cells would survive longer. This is in contrast with our findings where the CD30-deficient animals had lower numbers of $\mathrm{T}$ cells responding to infection. Also, the amounts of IL-4 induced in our system are always low to undetectable. Thus, we favor the opposite hypothesis that CD30 triggering activates survival pathways rather than promoting $\mathrm{T}$ cell death. Preliminary studies using flow cytometric analysis following staining with annexin $\mathrm{V}$ failed to show an increased rate of apoptosis of lymphocytes from CD30-deficient mice during infection (unpublished data). However, given the long timeframe of the response to infection and the rapid removal of apoptotic cells, the assay may be inadequate to address the mechanism of $\mathrm{T}$ cell loss. Although a decrease in lymphocyte proliferation or diminished cell recruitment could explain the reduced lymphocyte counts detected in CD30-deficient mice, several data from this report favor a role of CD30 in lymphocyte survival. First, granulomas in the $\mathrm{CD} 30^{-/-}$mice appear to form normally early in infection but appear to lose the lymphoid cells surrounding the central core of macrophages later on, consistent with a decreased survival of those cells. It should be stressed however that this occurred over a protracted period of time of up to 8 months, suggesting that the defect is only minor as compared with other examples of reduced $\mathrm{T}$ cell survival. Second, we found that lymphoproliferation was not reduced in uninfected or infected B6.CD30 $0^{-1-}$ mice as compared with control animals. Yet, further studies are still re- 
quired to definitely exclude the possible defects in lymphocyte migration and proliferation in the mutant mice.

In addition to possible effects on $\mathrm{T}$ cell survival, CD30 signaling may as well promote differentiation of $\mathrm{T}$ cells to a protective phenotype, namely by increasing the ability of these cells to produce IFN- $\gamma$. We presented evidence that the lack of CD30 impacted negatively on the ability of CD4 ${ }^{+} \mathrm{T}$ cells to polarize adequately into type 1 , IFN- $\gamma$-producing subsets. The amount of cytokine produced on a per-cell basis was significantly reduced in CD30-deficient mice as compared with the control animals. This defect was not explained by reduced IL-12p40 expression, but expression of other cytokines not tested here and required for such polarization may be affected. The lower numbers of $\mathrm{CD} 4^{+} \mathrm{T}$ cells plus the reduced ability of each cell to secrete IFN- $\gamma$ are expected to lead to overall reduced concentrations of this cytokine at the infected sites. Yet, sufficient quantities of this cytokine were still produced to lead to normal granuloma structuring and to control of infection, albeit at slightly higher loads than in control animals. Although $\mathrm{CD}^{+} \mathrm{T}$ cells may produce IFN- $\gamma$, and their numbers appeared to be reduced in infected CD30-deficient mice, we have shown previously that this $\mathrm{T}$ cell population does not contribute to resistance to infection by $M$. avium [38] and therefore did not characterize here their function in this model.

Our data are consistent with the recent work of Saraiva et al. [16], who have shown that a poxvirus homologue of CD30 was able to block CD30-CD153 interactions and to inhibit the generation of IFN- $\gamma$ responses. In vitro generation of alloreactive $\mathrm{T}$ cells and in vivo sensitization with mycobacterial antigens were studied by these authors, and the presence of the soluble, viral CD30 molecule was shown to reduce priming of IFN- $\gamma$-producing $\mathrm{T}$ cells and in the latter case, to reduce granuloma formation [16]. In contrast, no effect on Th2 responses was found.

In summary, we report about the role of CD30-CD153 interactions in the costimulation of $\mathrm{T}$ cell-mediated immunity to mycobacterial infection through a pathway that involves IFN- $\gamma$.

\section{ACKNOWLEDGMENTS}

This work was supported by Grants POCTI/32629/99 and PSIDA/MGI/49647/2003 from the Portuguese Science and Technology Foundation (FCT; Portugal) and SDH.IC.I.01.15 from the Calouste Gulbenkian Foundation (Portugal). M. F. received a fellowship from the FCT. The authors are indebted to Isabel Dantas, Alexandra Rêma, Fátima Faria, and Célia Lopes for their technical help.

\section{REFERENCES}

1. Locksley, R. M., Killeen, N., Lenardo, M. J. (2001) The TNF and TNF receptor superfamilies: integrating mammalian biology. Cell 104, 487501

2. Croft, M. (2003) Co-stimulatory members of the TNFR family: key to effective T-cell immunity? Nat. Rev. Immunol. 3, 609-620.

3. Hintzen, R. Q., Lens, S. M. A., Lammers, K., Kuiper, H., Beckmann, M. P., van Lier, R. A. W. (1995) Engagement of CD27 with its ligand
CD70 provides a second signal for T cell activation. J. Immunol. 154, 2612-2623.

4. Hendriks, J., Gravestein, L. A., Tesselaar, K., van Lier, R. A. W., Schumacher, T. N. M., Borst, J. (2000) CD27 is required for generation and long-term maintenance of T cell immunity. Nat. Immunol. 1, 433440.

5. Arens, R., Tesselaar, K., Baars, P. A., Schijndel, G. M. W., Hendriks, J., Pals, S. T., Krimpenfort, P., Borst, J., van Oers, M. H. J., van Lier, R. A. W. (2001) Constitutive CD27/CD70 interaction induces expansion of effector-type T cells and results in IFN $\gamma$-mediated B cell depletion. Immunity 15, 801-812.

6. Tesselaar, K., Arens, R., van Schijndel, G. M. W., Baars, P. A., van der Valk, M. A., Borst, J., van Oers, M. H. J., van Lier, R. A. W. (2003) Lethal $\mathrm{T}$ cell immunodeficiency induced by chronic costimulation via CD27CD70 interactions. Nat. Immunol. 4, 49-54.

7. Nakajima, A., Oshima, H., Nohara, C., Morimoto, S., Yoshino, S., Kobata, T., Yagita, H., Okumura, K. (2000) Involvement of CD70-CD27 interactions in the induction of experimental autoimmune encephalomyelitis. J. Neuroimmunol. 109, 188-196.

8. del Prete, G., de Carli, M., Almerigogna, F., Daniel, C. K., d'Elios, M. M., Zancuoghi, G., Vinante, F., Pizzolo, G., Romagnani, S. (1995) Preferential expression of CD30 by human CD4 ${ }^{+} \mathrm{T}$ cells producing Th2-type cytokines. FASEB J. 9, 81-86.

9. Amakawa, R., Hakem, A., Kundig, T. M., Matsuyama, T., Simard, J. J. L., Timms, E., Wakeham, A., Mittruecker, H-W., Griesser, H., Takimoto, H., Schmits, R., Shahinian, A., Ohashi, P. S., Penninger, J. M., Mak, T. W. (1996) Impaired negative selection of T cells in Hodgkin's disease antigen CD30-deficient mice. Cell 84, 551-562.

10. Bengtsson, A., Joahansson, C., Linder, M. T., Halldén, G., van der Ploeg, I., Scheynus, A. (1995) Not only Th2 cells but also Thl cells express CD30 after activation. J. Leukoc. Biol. 58, 683-689.

11. de Young, A. L., Duramad, O., Winoto, A. (2000) The TNF receptor family member CD30 is not essential for negative selection. J. Immunol. 165, $6170-6173$.

12. Gilfillan, M. C., Noel, P. J., Podack, E. R., Reiner, S. L., Thompson, C. B. (1998) Expression of the costimulatory receptor CD30 is regulated by both CD28 and cytokines. J. Immunol. 160, 2180-2187.

13. Nakamura, T., Lee, R. K., Nam, S. Y., Al-Ramadi, B. K., Koni, P. A., Bottomly, K., Podack, E. R., Flavell, R. A. (1997) Reciprocal regulation of CD30 expression on CD4 $4^{+}$T cells by IL- 4 and IFN- $\gamma$. J. Immunol. 158 , 2090-2098.

14. Duckett, C. S., Thompson, C. B. (1997) CD30-dependent degradation of TRAF2: implications for negative regulation of TRAF signaling and the control of cell survival. Genes Dev. 11, 2810-2821.

15. Seah, G. T., Rook, G. A. W. (2001) IL-4 influences apoptosis of Mycobacterium-reactive lymphocytes in the presence of TNF- $\alpha$. J. Immunol. 167, 1230-1237.

16. Saraiva, M., Smith, P., Fallon, P. G., Alcami, A. (2002) Inhibition of type 1 cytokine-mediated inflammation by a soluble CD30 homologue encoded by ectromelia (mousepox) virus. J. Exp. Med. 196, 829-839.

17. Salek-Ardakani, S., Song, J., Halteman, B. S., Jember, A. G-H., Akiba, H., Yagita, H., Croft, M. (2003) OX40 (CD134) controls memory T helper 2 cells that drive lung inflammation. J. Exp. Med. 198, 315-324.

18. Akiba, H., Miyahira, Y., Atsuta, M., Takeda, K., Nohara, C., Futagawa, T., Matsuda, H., Aoki, T., Yagita, H., Okumura, K. (2000) Critical contribution of OX40 ligand to T helper cell type 2 differentiation in experimental leishmaniasis. J. Exp. Med. 191, 375-380.

19. Pippig, S. D., Pena-Rossi, C., Long, J., Godfrey, W. R., Fowell, D. J., Reiner, S. L., Birkeland, M. L., Locksley, R. M., Barclay, A. N., Killeen, N. (1999) Robust B cell immunity but impaired T cell proliferation in the absence of CD134 (OX40). J. Immunol. 163, 6520-6529.

20. Nohara, C., Akiba, H., Nakajima, A., Inoue, A., Koh, C-S., Ohshima, H., Yagita, H., Mizuno, Y., Okumura, K. (2001) Amelioration of experimental autoimmune encephalomyelitis with anti-OX40 ligand monoclonal antibody: critical role for OX40 ligand in migration, but not development, of pathogenic T cells. J. Immunol. 166, 2108-2115.

21. Weinberg, A. D., Wegmann, K. W., Funatake, C., Whitham, R. H. (1999) Blocking OX-40/OX40 ligand interaction in vitro and in vivo leads to decreased $\mathrm{T}$ cell function and amelioration of experimental allergic encephalomyelitis. J. Immunol. 162, 1818-1826.

22. Kopf, M., Ruedl, C., Schmitz, N., Gallimore, A., Lefrang, K., Ecabert, B., Odermatt, B., Bachmann, M. F. (1999) OX40-deficient mice are defective in Th cell proliferation but are competent in generating B cell and CTL responses after virus infection. Immunity 11, 699-708.

23. Chen, A. I., McAdam, A. J., Buhlmann, J. E., Scott, S., Lupher, M. L., Greenfield, E. A., Baum, P. R., Fanslow, W. C., Calderhead, D. M., Freeman, G. J., Sharpe, A. H. (1999) OX40-ligand has a critical costimulatory role in dendritic cell:T cell interactions. Immunity 11, 689-698. 
24. Kim, Y-J., Kim, S. H., Mantel, P., Kwon, B. S. (1998) Human 4-1BB regulates CD28 co-stimulation to promote Th1 cell responses. Eur. J. Immunol. 28, 881-890.

25. Cannons, J. L., Lau, P., Ghumman, B., de Benedette, M. A., Yagita, H., Okumura, K., Watts, T. H. (2001) 4-1BB ligand induces cell division, sustains survival, and enhances effector function of CD4 and CD8 T cells with similar efficacy. J. Immunol. 167, 1313-1324.

26. Shuford, W. W., Klussman, K., Tritchler, D. D., Loo, D. T., Chalupny, J., Siadak, A. W., Brown, T. J., Emswiler, J., Raecho, H., Larsen, C. P., Pearson, T. C., Ledbetter, J. A., Aruffo, A., Mittler, R. S. (1997) 4-1BB costimulatory signals preferentially induce CD8+ T cell proliferation and lead to the amplification in vivo of cytotoxic T cell responses. J. Exp. Med. 186, 47-55.

27. Tan, J. T., Whitmire, J. K., Ahmed, R., Pearson, T. C., Larsen, C. P. (1999) 4-1BB ligand, a member of the TNF family, is important for the generation of antiviral CD8 T cell responses. J. Immunol. 163, 4859-4868.

28. DeBenedette, M. A., Wen, T., Bachmann, M. F., Ohashi, P. S., Barber, B. H., Stocking, K. L., Peschon, J. J., Watts, T. H. (1999) Analysis of 4-1BB ligand (4-1BBL)-deficient mice and of mice lacking both 4-1BBL and CD28 reveals a role for 4-1BBL in skin allograft rejection and in the cytotoxic $\mathrm{T}$ cell response to influenza virus. J. Immunol. 163, 48334841.

29. Pedrosa, J., Flórido, M., Kunze, Z. M., Castro, A. G., Portaels, F., McFadden, J. J., Silva, M. T., Appelberg, R. (1994) Characterization of the virulence of Mycobacterium avium complex isolates in mice. Clin. Exp. Immunol. 98, 210-216.

30. Oshima, H., Nakano, H., Nohara, C., Kobata, T., Nakajima, A., Jenkins, N. A., Gilbert, D. J., Copeland, N. G., Muto, T., Yagita, H., Okumura, K. (1998) Characterization of murine CD70 by molecular cloning and mAb. Int. Immunol. 10, 517-526.

31. Akiba, H., Oshima, H., Takeda, K., Atsuta, M., Nakano, H., Nakajima, A., Nohara, C., Yagita, H., Okumura, K. (1999) CD28-independent costimulation of T cells by OX40 ligand and CD70 on activated B cells. J. Immunol. 162, 7058-7066.

32. Shimozato, O., Takeda, K., Yagita, H., Okumura, K. (1999) Expression of CD30 ligand (CD153) on murine activated T cells. Biochem. Biophys. Res. Commun. 256, 519-526.

33. Futagawa, T., Akiba, H., Kodama, T., Takeda, K., Hosoda, Y., Yagita, H., Okumura, K. (2002) Expression and function of 4-1BB and 4-1BB ligand on murine dendritic cells. Int. Immunol. 14, 275-286.

34. Pais, T. F., Cunha, J. F., Appelberg, R. (2000) Antigen specificity of the $\mathrm{T}$ cell response to Mycobacterium avium infection in mice. Infect. Immun. 68, 4805-4810.

35. Flórido, M., Gonçalves, A. S., Silva, R. A., Ehlers, S., Cooper, A. M., Appelberg, R. (1999) Resistance of virulent Mycobacterium avium to interferon- $\gamma$-mediated antimicrobial activity suggests additional signals for induction of mycobacteriostasis. Infect. Immun. 67, 3610-3618.

36. Flórido, M., Cooper, A. M., Appelberg, R. (2002) Immunological basis of the development of necrotic lesions following Mycobacterium avium infection. Immunology 106, 590-601.

37. Appelberg, R., Soares, R., Ferreira, P., Silva, M. T. (1989) Induction of nonspecific immunosuppression in mice by mycobacterial infections and its relation to macrophage activation. Scand. J. Immunol. 30, 165-174.

38. Appelberg, R., Castro, A. G., Pedrosa, J., Silva, R. A., Orme, I. M., Minóprio, P. (1994) The role of $\gamma$ interferon and tumor necrosis factor- $\alpha$ during the $\mathrm{T}$ cell independent and dependent phases of Mycobacterium avium infection. Infect. Immun. 62, 3962-3971.

39. Flórido, M., Gonçalves, A. S., Gomes, S., Appelberg, R. (2004) CD40 is required for optimal induction of protective immunity to Mycobacterium avium. Immunology 111, 323-327.

40. Gomes, M. S., Flórido, M., Cordeiro, J. V., Teixeira, C. M., Takeuchi, O., Akira, S., Appelberg, R. (2004) Limited role of the Toll-like receptor (TLR)-2 in resistance to Mycobacterium avium. Immunology 111, 179185

41. Flynn, J. L., Goldstein, M. M., Chan, J., Triebold, K. J., Pfeffer, K., Lowenstein, C. J., Schreiber, R., Mak, T. W., Bloom, B. R. (1995) Tumor necrosis factor- $\alpha$ is required in the protective immune response against Mycobacterium tuberculosis in mice. Immunity 2, 561-572.

42. Kindler, V., Sappino, A. P., Grau, G. E., Piguet, P. F., Vassalli, P. (1989) The inducing role of tumour necrosis factor in the development of bactericidal granulomas during BCG infection. Cell 56, 731-740.

43. Roach, D. R., Briscoe, H., Saunders, B., France, M. P., Riminton, S., Britton, W. J. (2001) Secreted lymphotoxin- $\alpha$ is essential for the control of an intracellular bacterial infection. J. Exp. Med. 193, 239-246.

44. Bean, A. G. D., Roach, D. R., Briscoe, H., France, M. P., Korner, H., Sedgwick, J. D., Britton, W. J. (1999) Structural deficiencies in granuloma formation in TNF gene-targeted mice underlie the heightened susceptibility to aerosol Mycobacterium tuberculosis infection, which is not compensated for by lymphotoxin. J. Immunol. 162, 3504-3511.

45. Bopst, M., Garcia, I., Guler, R., Olleros, M. L., Rulicke, T., Muller, M., Wyss, S., Frei, K., le Hir, M., Eugster, H-P. (2001) Differential effects of TNF and LT $\alpha$ in the host defense against M. bovis BCG. Eur. J. Immunol. 31, 1935-1943.

46. Jacobs, M., Brown, N., Allie, N., Ryffel, B. (2000) Fatal Mycobacterium bovis BCG infection in TNF-LT- $\alpha$-deficient mice. Clin. Immunol. 94, 192-199.

47. Appelberg, R., Sarmento, A., Castro, A. G. (1995) Tumor necrosis factor $\alpha(\mathrm{TNF} \alpha)$ in the host resistance to mycobacteria of distinct virulence. Clin. Exp. Immunol. 101, 308-313. 